\title{
OS COLUMNATUM AGAIN: PLAUTUS, MILES GLORIOSUS 211
}

\author{
Andrew Gallia
}

As Palaestrio works to formulate a plan, Periplectomenus looks on and describes the sequence of physical gestures through which the wily slave manifests his mental exertions. It is not difficult for the modern reader to imagine the sight gags that might have accompanied this little monologue, but Periplectomenus' reaction to one pose presents its own interpretative challenges (Plaut. Mil. 209-212): ${ }^{1}$

ecce autem aedificat: columnam mento suffigit suo. apage, non placet profecto mihi illaec aedificatio; nam os columnatum poetae esse indaudivi barbaro, quoi bini custodes semper totis horis occubant.

But see now what he's building: he puts a column under his chin. Get away! I really can't stand that construction there; for I heard that a face was put on a column for a barbarian poet, who has two guards constantly looming over him, day and night.

This passage has long been recognized as a reference to the imprisonment of the playwright $\mathrm{Cn}$. Naevius, who famously courted danger by writing nasty things about such

\footnotetext{
* Published in Classical Philology 115.4.

${ }^{1}$ I rely on Lindsay's OCT (1905) for the text of Plautus. Translations are my own.
} 
prominent persons as Scipio Africanus, whom he accused of sexual impropriety, and the Caecilii Metelli, whose tenure of the consulship he described as "fateful for Rome."2 Naevius' reputation as a political provocateur has sometimes been called into question, however, and there are a number of scholars who would dismiss the story as a myth, invoking the general unreliability of ancient traditions of literary biography. ${ }^{3}$

Such extreme skepticism is unwarranted, because these lines appear to offer independent corroboration that something did, in fact, happen to Naevius. We may

${ }^{2}$ Gell. NA 3.3.15 (imprisonment), 7.8.5 (= Naev. Com. 108-10R, derogatory verses about Scipio); [Asc.] Verr. 1.29 (fato Metelli Romae fiunt consules). See, inter alia, Frank 1927; Hammond et al. 1963, 96; Fantham 2014, 327; with Suerbaum 2002, 104-6 for an overview of the bibliography.

${ }^{3}$ Leo 1912, 77-78; Mattingly 1960, 415-26; Gruen 1996, 96-104, Manuwald 2015, 97. An influential argument against a political interpretation of Naevius' work is that of Wright (1974, 33-59), although he does not address the issue of incarceration explicitly. As I see it, the case for skepticism rests on an overly schematic application of the traditional Peripatetic distinction between "Old" and "New" Comedy: cf. Csapo 2000. To demonstrate that Naevius dealt with Menandrian-style domestic plots proves nothing about the political implications of individual passages. Cf. now Beta (2014), who sets out to defend the tradition by identifying "Aristophanic" themes in Naevius' fragments. An ambiguous fragment of Cicero's Republic (4.11, ap. August. De civ. D. 2.9) is also regularly invoked to show that political commentary was impossible on the Roman stage, even though this was manifestly not the case in Cicero's own day: cf. Cic. Sest. 115-18, Att. 2.19.3. 
concede that the adjective barbaro is too vague to provide a positive identification in isolation, even though it is explicitly cited as an epithet that Plautus used to describe his fellow playwright Naevius (Paul. Fest. 32L). The unwelcome prospect of a "barbarian" (i.e., Latin-speaking) poet being placed under guard nevertheless remains, and Naevius must be regarded as the most likely candidate for such a scenario. ${ }^{4}$ The connection therefore stands and Naevius' arrest, which scholars typically assign to 206 BC, can be used to establish a context for the Miles Gloriosus. ${ }^{5}$

Establishing the identity of the unnamed barbarian poet has done little to unlock the riddle posed by the unusual phrase os columnatum in line 211 , however. Over the years, this reference to a face placed on a column has been glossed variously as a figurative account of Naevius' mournful posture while imprisoned, ${ }^{6}$ a literal description of the restraining device employed to hold him fast, ${ }^{7}$ and an allusion to the sexual abuse to which the poet was subjected (metaphorically, one hopes) by his noble antagonists. ${ }^{8}$

\footnotetext{
${ }^{4}$ Pace Fontaine (2020), who identifies the barbarian poet as Sotades of Maroneia. For barbarus as Latin-speaking, cf. Plaut. Asin. 11, Trin. 19, Capt. 884. Repeated references to Sceledrus' assigned task in the Miles itself $(146,153,271,298,305,467,550)$ offer sufficient attestation for the use of custos in the sense of "guard": cf. Allen 1896, 64; pace Mattingly 1960, 423.

${ }^{5}$ Jocelyn 1969, 35-7; Schaaf 1977, 373-7.

${ }^{6}$ Brix and Niemeyer 1901, 50.

${ }^{7}$ Allen 1896; Marx 1911, 75; cf. Jocelyn 1969, 36.

${ }^{8}$ Killeen 1973; Lambinus 1576, 669: Sed quod de ore columnato diximus, nonnulli flagitiose accipiunt. nam per os columnatum, os irrumatum intelligi volunt.
} 
Although the proliferation of interpretations is unlikely to lead to consensus, I nevertheless would like to call attention to the architectural vocabulary used in this passage. The echoing of cognate verb-noun pairs aedificat ... aedificatio and columnam ... columnatum suggests that the actor's posture was not being compared with that of Naevius himself, but rather with the form of some kind of structure or monument. Looking beyond the most literal interpretation of the clause's grammar (wherein os is the subject of columnatum ... esse), it is possible that Plautus intended for his audience to think of a column on which a face of some sort appeared.

The context for Naevius' association with such a monument can be readily identified. In his account of the poet's legal tribulations, Marx rightly called attention to the irony of the fact that Naevius' imprisonment seems to have occurred just as poetry was beginning to gain a measure of respectability in Rome. ${ }^{9}$ In $207 \mathrm{BC}$, on the heels of the disastrous ambush at Venusia and the news of Hasdrubal's preparations for a second invasion of Italy, the priestly colleges arranged for a chorus of twenty-seven matrons to perform a special hymn composed by the poet Livius Andronicus (Livy 27.37.7-15). The destruction of Hasdrubal's army at the Metaurus River soon thereafter provided confirmation of the successful restoration of the gods' favor. So relieved were the Roman people, they elected the legates who had been sent to announce the news of this victory as the consuls for the following year (Livy 28.9.19). One of these men was Q. Metellus, who had not yet held the praetorship.

Perhaps tendentiously, Festus connects these events with the establishment of new honors for scribae (i.e., poets) and histriones (actors) at this time (Fest. 446-8L):

\footnotetext{
${ }^{9}$ Marx 1911, 72. Cf. Gruen 1996, 85-9.
} 
... quia prosperius respublica populi Romani geri coepta est, publice adtributa est ei in Aventino aedis Minervae, in qua liceret scribis histrionibusque consistere ac dona ponere; in honorem Livi, quia is et scribebat fabulas et agebat.

because the public affairs of the Roman people started to be conducted with greater fortune, a part of the temple of Minerva on the Aventine was publicly granted to him, in which it was permitted for writers and actors to assemble and place gifts; this was an honor for Livius, because he both wrote plays and performed in them.

The question of why actors shared in this dispensation when Livius was being honored for his work as a lyricist can be set aside for the time being. ${ }^{10}$ What is important for our purposes is that, in or around 207 or $206 \mathrm{BC}$, poets were given the right to set up gifts in the temple of Minerva on the Aventine. What kind of dedications were made and by whom is not recorded; the earliest known Roman comparandum appears to be the oversized statue that Accius set up of himself in the temple of the Camenae a few generations later (Plin. HN 34.19). It is at least plausible that Naevius, who like Accius was remembered for his arrogance (Gell. NA 1.24.2, cf. Val. Max. 3.7.11), would have availed himself of the opportunity to make a dedication in the newly established collegial sanctuary. This would have been around the same time that Metellus was elected consul

\footnotetext{
${ }^{10}$ Horsfall 1976, 81.
} 
and thus became a target for one of the insulting remarks that precipitated Naevius' arrest.

With regard to the format of Naevius' potential gift, the use of columns as supports for honorific dedications was a well-established custom in Rome by the end of the third century BC. Pliny the Elder (HN 34.20-21) mentions three famous examples of this "more ancient" practice, the most enduring of which was the rostral column of C. Duilius, set up in the Forum and decorated with the spoils from his naval victory at Mylae in 260 BC. ${ }^{11}$ Such columns appear to have been surmounted by full portrait statues, however, and so may not provide an exact parallel for Plautus' description of an os columnatum.

Perhaps, in keeping with the predominantly theatrical associations of the Aventine precinct, the face $(o s)$ on Naevius' column was actually an actor's mask. ${ }^{12}$ Vergil was able to imagine primitive Ausonian farmers performing in rough-hewn ora and setting up oscilla on pine trees as dedications for Bacchus (G. 2.385-9; cf. Fest. 212L, Macrob. Sat. 1.7.31). This evidence is more evocative than probative, but the dedication of comic masks in temples was certainly an established practice within the dramatic culture of the

${ }^{11}$ Wallace-Hadrill 1990, 172; Kondratieff 2004. Cf. Enn. Scipio 1-2 V (ap. SHA Claud. 7.6): quantam statuam faciet populus Romanus, quantam columnam quae res tuas gestas loquatur.

${ }^{12}$ For os in this sense, see TLL 9.2, 1088, 11. 26-30. The question of whether masks were worn in early Roman drama (denied by Diomedes, CGL I: 489) need not detain us, since Naevius was the author of a play entitled Personata (Fest. 238L): see Manuwald 2011, 79-80. 
Greek and Hellenistic world. ${ }^{13}$ It would not have been implausible for Naevius, who did so much to foster the establishment of Greek theatrical traditions at Rome, to propagate a similar custom when given the opportunity.

Naevius' os columnatum might thus have resembled the masked pillars known from depictions of certain Dionysian rituals in Attic vase paintings. ${ }^{14}$ Some scholars consider these rustic assemblages the precursors of the Athenian herm statue, which also merits consideration as a possible model for Naevius' hypothetical dedication. ${ }^{15}$ Among the materials uncovered during excavations in the area of the Athenian agora known in antiquity as "the herms" is the base of a herm pillar with an inscription recording a late fifth- or early fourth-century dedication in honor of the victors of comic and tragic competitions. ${ }^{16}$ Such a dedication could have had something to do with the worship of Hermes Epagonios, who presided over games. ${ }^{17}$ The incarnation of Hermes Logios is also especially relevant when thinking about a statue type that could be described as an os columnatum, however. The very format of the herm, which emphasizes the head of the figure rather than the entire physique, was interpreted by some ancient writers as a

${ }^{13}$ Lys. 21.4, cf. Anth.Pal. 6.308, 310-11. Green 1982.

${ }^{14}$ E.g., CVA 7.1 pl. 13 (Villa Giulia). Wrede 1928; Pickard-Cambridge 1988, 30-34. ${ }^{15}$ Goldman 1942.

${ }^{16}$ SEG 32.239; Shear 1971, 256; Edmonson 1982. The competitions were presumably those of the Lenaian festival, which Onesippos, the dedicator of the herm, oversaw as archon basileus (cf. [Arist.] Ath. Pol. 57).

${ }^{17} I G \mathrm{II}^{2} 3023$, Ar. Plut. 1161. Cf. the gallery of second-century AD portrait herms of charioteers discovered in the temple of Hercules Cubans in Rome: Nash 1961, I: 462-70. 
reflection of the importance of speech (and thus the mouth/face) for the identity of Hermes as a messenger-god. ${ }^{18}$ As such, the herm provided an apt format for a dedication by a poet. ${ }^{19}$

Beyond adding to an already ample store of speculation about the meaning of $o s$ columnatum, the interpretation tentatively presented here is recommended by the fact that it allows for a more nuanced understanding of the reaction that Palaestrio's posture elicits from his viewer. After banishing the displeasing aedificatio in line 210, Periplectomenus goes on to praise Palaestrio's next pose, in which he has apparently fallen asleep: eugae! euscheme hercle astitit et dulice et comoedice (213, "Well done! He stands by in proper form, both slavishly and comically"). If os columnatum refers to a means of incarceration, the contrast with something that is now appropriately "slavish" makes little sense, insofar as physical detention was a reality that Roman slaves had to contend with on a regular basis, even on the comic stage (cf. Plaut. Asin. 300-306). If, on the other hand, the phrase refers to some sort of self-glorifying monument, then the nature of the

${ }^{18}$ Wrede 1985, 12-17. Paul. Fest. 45L: Cyllenius Mercurius dictus, quod omnem rem sermo sine manibus conficiat, quibus partibus corporis qui carent $\kappa v \lambda \lambda o i ́$ vocantur, ideoque quadratum eum fingunt. Cf. Plaut. Amph. 12.

${ }^{19}$ Although the association with Hermes Logios has been invoked to explain the emergence of the herm as the predominant format for portraits of poets, orators, and intellectuals in the late Republic, Naevius' dedication is unlikely to have taken the form of a portrait herm. By all accounts, this was a later development in the history of GrecoRoman art: see Wrede 1985, 71-77; Dillon 2006, 31. 
contrast becomes clearer, as does its relevance to the theme of the alazōn, or braggart, at the center of the play (cf. Mil. 86-7).

In light of the reference to the custodes in the intervening line, the implication that a comic posture is also a slavish one might also carry an additional, darker undertone. Unlike the overassertive but ultimately humbled Naevius, Plautus knows that he must be careful to confine his comedy within proper limits. This difference in poetic temperament could have been underscored with a reference to Naevius' triumphant dedication of an os columnatum, which would serve as a symbol of the pridefulness that preceded his fall. Through Periplectomenus' reactions, Plautus signals that he will have none of that. Instead, he playfully aligns himself with the more abject, but safer, position of a servile comedian. 


\section{LITERATURE CITED}

Allen, Frederic D. 1896. On 'os columnatum' (Plaut. M.G. 211) and Ancient Instruments of Confinement. HSCP 7: 37-64.

Beta, Simone. 2014. Libera lingua loquemur ludis Liberalibus: Gnaeus Naevius as a Latin Aristophanes? In Ancient Comedy and Reception. Essays in Honor of Jeffrey Henderson, ed. S. Douglas Olson, 203-22. Berlin.

Brix, Julius and Niemeyer, Max, eds. 1901. Ausgewählte Komödien des T. Maccius Plautus, viertes Bändschen: Miles Gloriosus. 3rd edn. Leipzig.

Csapo, Eric. 2000. From Aristophanes to Menander? Genre Transformation in Greek Comedy. In Matrices of Genre: Authors, Canons, and Society, ed. Mary Depew and Dirk Obbink, 115-33. Cambridge, MA.

Dillon, Sheila. 2006. Ancient Greek Portrait Sculpture. Cambridge.

Edmonson, Colin N. 1982. Onesippos' Herm. In Studies in Attic Epigraphy, History and Topography presented to Eugene Vanderpool. Hesperia Suppl. 19, 48-50. Princeton.

Fantham, Elaine. 2014. Literature in the Roman Republic. In The Cambridge Companion to the Roman Republic ${ }^{2}$, ed. Harriet I. Flower, 323-47. Cambridge.

Fontaine, Michael. 2020. Before Pussy Riot: Free Speech and Censorship in the Age of Plautus. In Plautus' Erudite Comedy, ed. Sophia Papaioannou and C. Demetriou, 239-63. Newcastle upon Tyne.

Frank, Tenney. 1927. Naevius and Free Speech. AJP 48: 105-110.

Goldman, Hetty. 1942. The Origin of the Greek Herm. AJA 46: 58-68. 
Green, John R. 1982. Dedications of Masks. RA n.s. 2: 237-48.

Gruen, Erich S. 1996 (orig. 1990). Studies in Greek Culture and Roman Policy. Berkeley.

Hammond, Mason, Mack, Arthur M., and Moskalew, Walter, eds. 1963. T. Macci Plauti Miles Gloriosus. Revised edn. Cambridge, MA.

Horsfall, Nicholas. 1976. The Collegium Poetarum. BICS 23: 79-95.

Jocelyn, Henry D. 1969. The Poet Cn. Naevius, P. Cornelius Scipio and Q. Caecilius Metellus. Antichthon 3: 32-47.

Kondratieff. Eric. 2004. The Column and Coinage of C. Duilius: Innovations in Iconography in Large and Small Media. SCI 23: 1-39.

Killeen, J. F. 1973. Plautus Miles Gloriosus 211. CP 68: 53-4.

Lambinus, Dionysius. 1576. M. Accius Plautus ex Fide atque Auctoritate Complurium Librorum Manuscriptorum Opera. Paris.

Lindsay, Wallace M. 1905. T. Macci Plavti Comoediae. Oxford.

Leo, Friedlich. 1912. Plautinische Forschungen. 2nd edn. Berlin.

Manuwald, Gesine. 2011. Roman Republican Theatre. Cambridge. 2015. Censorship for the Roman Stage? In The Art of Veiled Speech: SelfCensorship from Aristophanes to Hobbes, ed. Hans Baltussen and Peter J. Davis, 94-114. Philadelphia.

Marx, Friedrich. 1911. Naevius. Berichte über die Verhandlungen der königlich sächsischen Gesellschaft der Wissenschaften, Philologisch-historische Klasse 63: $39-82$.

Mattingly, Harold B. 1960. Naevius and the Metelli. Historia 9: 414-39.

Nash, Ernest. 1961. Pictorial Dictionary of Ancient Rome. 2 volumes. New York. 
Pickard-Cambridge, Arthur. 1988. The Dramatic Festivals of Athens, ${ }^{2}$ rev. John Gould and D. M. Lewis. Oxford.

Schaaf, Lothar. 1977. Der Miles Gloriosus des Plautus und sein griechisches Original. Ein Beitrag zur Kontaminationsfrage. Munich.

Shear, T. Leslie. 1971. The Athenian Agora: Excavations of 1970. Hesperia 40: 241-79.

Suerbaum, Werner, ed. 2002. Handbuch der lateinischen Literatur der Antike I: Die archaische Literatur von den Anfängen bis Sullas Tod. Munich.

Wallace-Hadrill, Andrew. 1990. Roman Arches and Greek Honours: The Language of Power at Rome. PCPS 36: 143-81.

Wright, John. 1974. Dancing in Chains: The Stylistic Unity of the Comoedia Palliata. Rome.

Wrede, Henning. 1985. Die antike Herme. Mainz am Rhein.

Wrede, Walther. 1928. Der Maskengott. AM 53: 66-96. 